\title{
Antibiotic prescribing practices by South Australian general dental practitioners
}

\author{
Tom Jaunay,* Paul Sambrook, $†$ Alastair G ossł
}

\begin{abstract}
The prescribing habits of a randomly selected approximately 10 per cent sample of South Australian general dental practitioners were obtained by postal questionnaire. Sixty-eight (61 per cent) usable replies were received and analysed. Generally, there was an appropriate level of knowledge of antibiotic prescription. However, there was a tendency toward over-prescription and a demonstrated lack of knowledge of the incidence of adverse reactions, development of multiresistant strains and prophylaxis against bacterial endocarditis. All of these areas are real challenges to the profession, whether in an overall global community health sense or in a highly individualized clinical or medico-legal sense. These issues are discussed and the profession is urged to reconsider re-educate itself on these challenges.
\end{abstract}

Key words: Antibiotics, prescription, general dental.

(Received for publication November 1999. Revised

J anuary 2000. Accepted February 2000.)

\section{Introduction}

Antibiotics, along with analgesics, are the most commonly prescribed medications by dental practitioners. Antibiotics are considered a safe drug as they have no direct effect on the host, only attacking the bacterial microflora. This apparent safety has engendered an attitude of prescribing antibiotics for a wide variety of conditions 'just in case' of infection and patients often expect antibiotic prescription. There is increasing evidence that this attitude is totally inappropriate. ${ }^{1} \mathrm{Adverse}$ reactions, bacterial resistance rendering antibiotics useless and the rise of multiresistant bacteria are increasing problems. $^{2}$

Adverse reactions include vomiting, diarrhoea, rashes, anaphylaxis and sometimes death. ${ }^{3}$ Bacteria

\footnotetext{
*Oral and M axillofacial Surgery Registrar, Royal Hobart $\mathrm{H}$ ospital. $\dagger$ A ssistant D irector, Oral and M axillofacial Surgery U nit. ¥Professor and Director, Oral and M axillofacial Surgery U nit.

have the ability to mutate or acquire resistance so as to render particular antibiotics useless within one or two decades. ${ }^{4} \mathrm{~T}$ he development of resistance is not only a problem with the target bacteria in the condition being treated with antibiotics, other organisms within the body are also affected. ${ }^{5}$ The last decade has seen the emergence of multiresistant bacteria or 'superbugs' which do not respond to any antibiotic. ${ }^{2}$ Thus, in just over half a century, the possibility of a return to the pre-antibiotic era, when infections were a leading cause of death and disease, has emerged.

$M$ any guidelines for the rational use of antibiotics have been published. ${ }^{6,7} \mathrm{U}$ nfortunately, as these are often based on opinion as well as some microbiologic fact, they often give conflicting advice. For example, the recommendations for antibiotic prophylaxis against bacterial endocarditis secondary to dental treatment by UK, ${ }^{8} \mathrm{US}^{9}$ and Australian ${ }^{10-11}$ authorities differ. Indeed, in Australia, there are two different national guidelines, ${ }^{10-11}$ as well as many local institutional guidelines, ${ }^{12}$ leading to confusion and uncertainty.

This is further compounded by a lack of data on what individual practitioners prescribe. In an extensive study of Australian medical practitioners' prescribing habits, it was found that antibiotic usage in Australia was second only to F rance and higher than the UK and US. ${ }^{13}$ Antibiotics were still commonly being prescribed for upper respiratory tract infections when it is well known that these are invariably viral. It is also well documented that antibiotics do not prevent secondary infection from upper respiratory tract infections in healthy individuals. There were regional differences in prescription, with rural practitioners being more likely to prescribe antibiotics than urban medical practitioners.

Wide differences in antibiotic prescription for the same condition have been reported. In one study the most generous practitioner was 15 times more likely to prescribe an antibiotic than the most restrictive. ${ }^{14}$ 
Table 1. Periapical pathology

\begin{tabular}{|c|c|c|c|c|c|c|}
\hline \multirow{3}{*}{$\begin{array}{l}\text { Question } \\
\text { Clinical situation }\end{array}$} & \multicolumn{4}{|c|}{ Response } & \multicolumn{2}{|c|}{ Opinion } \\
\hline & \multicolumn{2}{|c|}{ Prescribe $a / b^{*}$} & \multirow[t]{2}{*}{ Type } & \multirow[t]{2}{*}{ Other treatment } & \multirow[t]{2}{*}{ Recommend } & \multirow[t]{2}{*}{ Overuse } \\
\hline & & & & & & \\
\hline \multicolumn{7}{|l|}{ Periapical pathology } \\
\hline no spread & $0 \%$ & $100 \%$ & - & E/E† immediately $46 \%$ & $E / E$ & $0 \%$ \\
\hline $\begin{array}{l}\text { chronic } \\
\text { asymptomatic }\end{array}$ & & & & E/E later $41 \%$ & No a/b & \\
\hline \multicolumn{7}{|l|}{ Periapical abscess } \\
\hline local swelling & $39 \%$ & $61 \%$ & Amoxycillin & $\mathrm{E} / \mathrm{E}$ drain $54 \%$ & E/E immediately & $39 \%$ \\
\hline $\begin{array}{l}\text { feel well } \\
\text { acute }\end{array}$ & & & $60 \%$ & E/E $27 \%$ & $\begin{array}{c}\text { Drain } \\
\text { No a/b }\end{array}$ & \\
\hline \multicolumn{7}{|l|}{ Cellulitis } \\
\hline feel ill & $98 \%$ & $2 \%$ & Amoxycillin & E/E immediately $26 \%$ & $\mathrm{E} / \mathrm{E}$ immediately & Under $21 \%$ \\
\hline feverish & & & $63 \%$ & $\begin{array}{c}\text { E/E drain } \\
24 \%\end{array}$ & $\begin{array}{l}\text { D rain } \\
\text { Give } a / b\end{array}$ & \\
\hline \multicolumn{7}{|l|}{ Endodontically debrided tooth } \\
\hline discharge & $28 \%$ & $72 \%$ & Amoxycillin & Redebride $90 \%$ & Redebride & $28 \%$ \\
\hline TTP & & & $50 \%$ & & $\mathrm{No} a / b$ & \\
\hline \multicolumn{7}{|l|}{ no swelling } \\
\hline \multicolumn{7}{|l|}{ Toothache } \\
\hline no observed dental cause & $2 \%$ & $98 \%$ & Cephalosporin & F urther investigate & F urther investigate & $2 \%$ \\
\hline
\end{tabular}

In another, the most generous practitioner prescribed 76 per cent of the time, while the most restrictive prescribed only 21 per cent of the time. ${ }^{15}$ Generally, the individual practitioner's attitude toward pharmacotherapy determines whether or not a patient is given a prescription.

$D$ ata are scarce on the prescribing habits of dental practitioners. A N orwegian study showed a restricted use of antibiotics by dental practitioners. ${ }^{16}$ In the representative week of the study, 32 per cent of the study population, which was 10 per cent of all dentists in N orway, did not prescribe an antibiotic. Five per cent of the study population did prescribe more than five times in the week. Periodontists, oral surgeons and those with research and teaching experience were more likely to prescribe antibiotics. Alarmingly, 32 per cent stated they never prescribed antibiotics for prophylaxis for patients with a history of endocarditis. US studies have shown a wider range of prescription of antibiotics both in terms of type and frequency. ${ }^{17}$ US dentists also had a high level of uncertainty about the use of antibiotics as prophylaxis for patients with a history of endocarditis. ${ }^{16}$

The aim of this study was to determine the antibiotic prescribing habits and knowledge of South Australian (SA) general dental practitioners.

\section{Method and materials}

A questionnaire on antibiotic prescribing was developed, based in part on a previous unpublished survey of dentists working in the public system. A trial of the questionnaire was carried out on a small group of experienced general dental practitioners and modified based on this experience.
It consisted of four sections: clinical scenarios for therapeutic prescription; questions on indications for prophylactic usage; general knowledge on antibiotics; and the demographics of the respondents. The questionnaire contained an insert listing 18 specific drug and dosage regimens plus the options to combine regimens or write in alternatives. (The questionnaire is available on written request.)

The two senior authors developed a 'correct answer' or opinion of appropriate treatment based on the established protocols of the Oral and $M$ axillofacial Surgery U nit. These are consistent with appropriate practice but do not follow a single reference guideline. From this, an overall score for each of the three sections was developed.

A random sample of 100 SA general dental practitioners was generated from the South Australian Dental Register - specialist practitioners were excluded. T he questionnaire was mailed as part of a package which included a covering letter explaining the reasons for the survey and confirming anonymity, as well as a prepaid reply envelope. Respondents were given the option of returning the questionnaire indicating they did not wish to participate or were no longer in active general practice. In this eventuality, a questionnaire was mailed to the succeeding general dentist on the Register. A followup was mailed at six and 12 weeks. The mailing was carried out by an administrative officer so the names and addresses of the respondents were not known to the researchers.

The data were transferred to a PC database and appropriate statistical analysis performed.

\section{Results}

Australian Dental J ournal 2000;45:3. 
Table 2. Surgery

\begin{tabular}{|c|c|c|c|c|c|c|}
\hline \multirow{3}{*}{$\begin{array}{l}\text { Question } \\
\text { Clinical situation }\end{array}$} & \multicolumn{4}{|c|}{ Response } & \multicolumn{2}{|c|}{ Opinion } \\
\hline & \multicolumn{2}{|c|}{ Prescribe $a / b *$} & \multirow{2}{*}{ Type } & \multirow{2}{*}{ Other treatment } & \multirow{2}{*}{ Recommend } & \multirow{2}{*}{ Overuse } \\
\hline & & No & & & & \\
\hline \multicolumn{7}{|l|}{ Extraction third molar } \\
\hline $\begin{array}{l}\text { asymptomatic } \\
\text { bone covered }\end{array}$ & $30 \%$ & $70 \%$ & $\begin{array}{c}\text { Amoxycillin } \\
80 \%\end{array}$ & - & $\mathrm{No} a / b$ & $30 \%$ \\
\hline \multicolumn{7}{|l|}{ Extraction third molar } \\
\hline $\begin{array}{l}\text { asymptomatic } \\
\text { oral comunics }\end{array}$ & $19 \%$ & $81 \%$ & $\begin{array}{c}\text { Amoxycillin } \\
90 \%\end{array}$ & - & $\mathrm{No} a / b$ & $19 \%$ \\
\hline \multicolumn{7}{|l|}{ Extraction third molar } \\
\hline $\begin{array}{l}\text { previous pericoronitis } \\
\text { asymptomatic }\end{array}$ & $34 \%$ & $66 \%$ & $\begin{array}{c}\text { Amoxycillin } \\
78 \%\end{array}$ & - & $\mathrm{No} a / \mathrm{b}$ & $34 \%$ \\
\hline \multicolumn{7}{|l|}{ Extraction third molar } \\
\hline current pericoronitis & $75 \%$ & $25 \%$ & $\begin{array}{l}\text { Amoxycillin } \\
90 \%\end{array}$ & - & $\begin{array}{l}\text { Leave and local } \\
\text { measures if exo } \\
\text { Give } a / b\end{array}$ & $\begin{array}{l}\text { Under } \\
25 \%\end{array}$ \\
\hline \multicolumn{7}{|l|}{ D entigerous cyst } \\
\hline $\begin{array}{l}\text { asymptomatic } \\
\text { small }\end{array}$ & $3 \%$ & $97 \%$ & Cephalosporin & L eave and review $50 \%$ & $\begin{array}{l}\text { Remove } \\
\text { No a/b }\end{array}$ & $3 \%$ \\
\hline Oro-antral fistula & $48 \%$ & $52 \%$ & $\begin{array}{c}\text { Amoxycillin } \\
75 \%\end{array}$ & $\begin{array}{c}\text { Refer } 65 \% \\
\text { Close immediately } \\
30 \%\end{array}$ & $\begin{array}{l}\text { Close immediately } \\
\qquad \mathrm{No} a / b\end{array}$ & $48 \%$ \\
\hline Avulsion and reimplantation tooth & $47 \%$ & $53 \%$ & $\begin{array}{l}\text { Amoxycillin } \\
50 \%\end{array}$ & Splint $72 \%$ & $\begin{array}{l}\text { Splint } \\
\text { Give } a / b\end{array}$ & $\begin{array}{l}\text { Under } \\
53 \%\end{array}$ \\
\hline
\end{tabular}

$* a / b=a n t i b i o t i c s$.

O ne hundred and seventeen surveys were mailed and 85 (73 per cent) were returned. Of these, five indicated they were no longer in active general dental practice and 12 declined to participate. Sixtyeight $(61 \%)$ usable replies were received.

The results of the five clinical situations related to periapical pathology are presented in Table 1 . In only one, the feverish, unwell patient with a cellulitis, was antibiotic prescription mandatory. All but one of the respondents prescribed antibiotics. Fifty per cent also correctly instituted concurrent treatment aimed at removing the cause and the one who did not prescribe relied on local measures alone. However,
49 per cent initially relied solely on the antibiotic. In the fit, well patient, with a localized infection, local treatment of the cause by drainage and removal of the tooth or pulp would have sufficed. Thirty-nine per cent of respondents gave an antibiotic, with eight relying initially on the antibiotic alone and treating the cause later. Twenty-eight per cent treated a draining sinus with antibiotics to cover the necessary endodontic redebridement. The remaining two scenarios, for which antibiotics had no indication, were appropriately treated.

The use of antibiotics prophylactically for surgery is presented in Table 2 . A pproximately 30 per cent of

Table 3. Mucosal and periodontal

\begin{tabular}{|c|c|c|c|c|c|c|}
\hline \multirow{3}{*}{$\frac{\text { Question }}{\text { Clinical situation }}$} & \multicolumn{4}{|c|}{ Response } & \multicolumn{2}{|c|}{ Opinion } \\
\hline & \multicolumn{2}{|c|}{ Prescribe $a / b *$} & \multirow[t]{2}{*}{ Type } & \multirow{2}{*}{ Other treatment } & \multirow{2}{*}{ Recommend } & \multirow{2}{*}{ Overuse } \\
\hline & & & & & & \\
\hline A cutely infected traumatic ulcer & $17 \%$ & $83 \%$ & Amoxycillin & $M$ anage cause $46 \%$ & Rinses and & $17 \%$ \\
\hline & & & $50 \%$ & $\begin{array}{c}\text { Rinses and manage } \\
\text { cause } 37 \%\end{array}$ & $\begin{array}{l}\text { manage cause } \\
\qquad \mathrm{No} \text { a/b }\end{array}$ & \\
\hline \multicolumn{7}{|l|}{ D enture patient } \\
\hline poor $\mathrm{OH}$ & $19 \%$ & $81 \%$ & Amphotericin $100 \%$ & L eave denture out & Cytology & $19 \%$ \\
\hline erythematous & & & & and mouth rinses $37 \%$ & L eave & \\
\hline sleeps with dentures in & & & & $\begin{array}{l}\text { L eave denture } \\
\text { out } 25 \%\end{array}$ & $\begin{array}{l}\text { denture out } \\
\text { M outh rinses }\end{array}$ & \\
\hline \multicolumn{7}{|l|}{ Acute necrotizing ulcerative } \\
\hline gingivitis & $80 \%$ & $20 \%$ & M etronidazole $84 \%$ & Scale immediately $57 \%$ & M outh rinses & Under \\
\hline & & & & & Give $a / b$ & $20 \%$ \\
\hline & & & & & Scale and clean later & \\
\hline \multicolumn{7}{|l|}{ Acute periodontitis } \\
\hline fit patient & $30 \%$ & $70 \%$ & Amoxycillin 20\% & - & Scale & $30 \%$ \\
\hline for scaling & & & $\begin{array}{l}\text { Tetracycline } 20 \% \\
\text { M etronidazole } 20 \%\end{array}$ & & $\mathrm{No} \mathrm{a} / \mathrm{b}$ & \\
\hline \multicolumn{7}{|l|}{ Chronic periodontitis } \\
\hline fit patient & $6 \%$ & $94 \%$ & M etronidazole $66 \%$ & - & Scale & $61 \%$ \\
\hline for scaling & & & Tetracycline 33\% & & $\mathrm{N}$ a/b & \\
\hline
\end{tabular}

*a/b=antibiotics. 
Table 4. Medical conditions requiring prophylactic antibiotic cover for high risk dental procedures

\begin{tabular}{lc}
\hline Condition & Correct response \% \\
\hline Previous bacterial endocarditis & 98 \\
Prosthetic heart valve & 96 \\
M itral valve incompetence & 86 \\
A trial septal defect with graft & 70 \\
Immunosuppressed patient & 65 \\
Atrial septal defect without graft & 63 \\
Patent ductus arteriosus & 62 \\
Head and neck radiotherapy & 54 \\
Heart murmur & 50 \\
Recent myocardial infarct & 44 \\
Diabetes (insulin dependent) & 13 \\
\hline
\end{tabular}

respondents routinely prescribed antibiotics for surgical situations where there was no evidence of infection. With symptoms or complexity, the percentage prescribing increased. There was an equal split for antibiotic usage for reimplantation of avulsed teeth.

The use of antibiotics for a range of mucosal and peridontal problems is presented in Table 3. The patient with acute necrotizing ulcerative gingivitis did have an active bacterial infection for which antibiotics were indicated. Eighty per cent of respondents did prescribe and predominantly used metronidazole. Most used the lower dose regimen and none used metronidazole in combination with a penicillin. Thirty per cent prescribed antibiotics for the patient with acute periodontitis. No particular antibiotic predominated with equal use of amoxycillin, tetracylines and metronidazole. Twenty per cent used antifungals for the patient with denture stomatitis. N one recommended fungal identification by cytology first.

Medical conditions which require antibiotic prophylaxis when high risk dental procedures are performed are presented in Table 4 . The essential indications related to preventing bacterial colonization of the damaged endocardium and protecting against bacterial infection for immunologically compromised patients. The key cardiac conditions of previous endocarditis and prosthetic heart valves were highly

Table 5. Medical conditions not requiring prophylactic antibiotic cover for high risk dental procedures

\begin{tabular}{lc}
\hline Condition & Correct response \% \\
\hline Carcinoma large intestine & 95 \\
Stroke & 90 \\
Orthopaedic plates & 84 \\
Old myocardial infarct & 82 \\
Femoral graft $>6$ months & 75 \\
Coronary bypass - surgery $>6$ months & 71 \\
Kidney failure & 69 \\
Rheumatic fever - no valvular damage & 64 \\
Hip prosthesis $>6$ months & 62 \\
\hline
\end{tabular}

Table 6. Identification of high risk dental procedures requiring antibiotic prophylaxis

\begin{tabular}{lc}
\hline Condition & Correct response \% \\
\hline Tooth extraction & 100 \\
Soft tissue surgery & 98 \\
Endodontic instrumentation beyond apex & 98 \\
Subgingival scaling & 96 \\
Subgingival polishing & 80 \\
Endodontic debridement & 72 \\
Placement crown with subgingival margins & 71 \\
Placement rubber dam & 53
\end{tabular}

identified. This level of identification reduced for other conditions. A grafted atrial septal defect, which is a high risk circumstance, was not covered by 30 per cent of respondents. An undefined heart murmur was equally covered or not covered. U nless urgent, dental treatment is best avoided for a patient with a myocardial infarct within the previous six weeks. Protection against bacterial infection for immunosuppressed patients, including insulin dependent diabetes, was low. Irradiated jaws are at risk of osteoradionecrosis and if hyperbaric oxygen is not available, antibiotics are indicated.

$M$ edical conditions that do not require antibiotic prophylaxis are presented in Table 5 . It must be noted that if antibiotics are prescribed 'just in case', then there is no benefit but a quantifiable risk. The patient with the history of rheumatic fever but no murmur was given antibiotics by 36 per cent of respondents. A similar number prescribed for the old hip prosthesis but much fewer for the orthopaedic plates.

Identification of those dental procedures that are high risk and thus require antibiotic prophylaxis is presented in Table 6. Generally, the guide is if a procedure produces bleeding, then it should be covered. The main clinical situations were accurately identified by over 90 per cent of respondents but only 53 per cent identified rubber dam placement as a high risk procedure.

Identification of low risk dental procedures that do not require antibiotic prophylaxis is presented in Table 7. A pparently, 9 per cent of respondents would prescribe antibiotics daily so at-risk patients could brush their teeth!

\section{Table 7. Identification of low risk dental procedures not requiring antibiotic prophylaxis}

\begin{tabular}{lc}
\hline Condition & Correct response \% \\
\hline Tooth brushing/flossing & 91 \\
Occlusal filling & 87 \\
Class III filling & 73 \\
L ocal anaesthetic injection & 67 \\
M atrix band & 66 \\
Endodontic obturation & 41 \\
\hline
\end{tabular}


Table 8. General knowledge questions about antibiotics

\begin{tabular}{|c|c|c|}
\hline Question & Answer & Correct response \\
\hline $\begin{array}{l}\text { Incidence of penicillin } \\
\text { allergy }\end{array}$ & $\begin{array}{l}1 \text { in } 100 \\
\text { (N ext option } \\
\quad 1 \text { in } 1000\end{array}$ & $22 \%$ \\
\hline $\begin{array}{l}\text { Incidence of cross-reactions } \\
\text { to cephalosporins }\end{array}$ & 1 in 5 & $63 \%$ \\
\hline $\begin{array}{l}\text { Relation of route to } \\
\text { allergic incidence }\end{array}$ & Same & $64 \%$ \\
\hline Alternative to penicillin & $\begin{array}{l}\text { Erythromycin } \\
\text { ineffective }\end{array}$ & $\begin{array}{l}80 \% \\
\text { erythromycin }\end{array}$ \\
\hline $\begin{array}{l}\text { Patient on oral } \\
\text { contraceptive } \\
\text { and antibiotics }\end{array}$ & $\mathrm{R}$ isk of interference & $\begin{array}{l}94 \% \text { would } \\
\text { prescribe }\end{array}$ \\
\hline M RSA stands for & $\begin{array}{l}\text { M ethicillin resistant } \\
\text { Staphylococcus } \\
\text { aureus }\end{array}$ & $\begin{array}{l}20 \% \\
\text { (41\% multi- } \\
\text { resistant) }\end{array}$ \\
\hline $\begin{array}{l}\text { Dentists' contribution } \\
\text { to M RSA }\end{array}$ & $\begin{array}{l}\text { Over-rescription } \\
\text { Low dose } \\
\text { Too long }\end{array}$ & $\begin{array}{l}62 \% \\
\text { ( } 1 \text { or more } \\
\text { correct } \\
\text { responses) }\end{array}$ \\
\hline
\end{tabular}

$T$ he responses to the general knowledge questions on antibiotics are presented in Table 8 . Generally, the level of knowledge was poor and 78 per cent underestimated the incidence of true penicillin allergy. Despite much media publicity and health bulletins to professionals, the awareness of methicillin resistant Staphylococcus aureus (M RSA) was low.

The demographics of the respondents are presented in Table 9. The respondents reflect the practice and education mix of SA dentists. The involvement in recent postgraduate courses was about 50 per cent greater than the general dentist population ( $T$ he U niversity of Adelaide Postgraduate Committee in Dentistry, personal communication, 1998). The scores for each of the three clinical sections, alone or in combination, were compared with each of the demographic characteristics. G enerally, there were few significant correlations. Length of time since graduation did show some significant correlation at the $p<0.05$ level. Graduates of 15 years or more had a lower score for the clinical scenarios, a lower score for general knowledge on antibiotics and a lower overall score. Involvement in postgraduate education showed a statistically significant relation $(p<0.05)$ to the correct use of antibiotics. T he greater the level of knowledge concerning antibiotics, as shown by the scores for the second and third sections of the questionnaire, then the lower the frequency of antibiotic prescription $(p<0.05)$.

\section{Discussion}

This study shows that a random sample of about 10 per cent of SA general dental practitioners has an appropriate knowledge of antibiotic prescription. When compared against a strict standard of indications for antibiotic prescription, there is a tendency to over-prescribe. There is also a
Table 9. Demographics of respondents

\begin{tabular}{lc}
\hline Practice type & \\
M ainly private & $67 \%$ \\
M ainly public & $33 \%$ \\
Practice location & \\
M etropolitan & $42 \%$ \\
Suburban & $46 \%$ \\
Rural & $12 \%$ \\
G raduation & \\
Adelaide & $87 \%$ \\
L ess than 15 years & $40 \%$ \\
M ore than 15 years & $60 \%$ \\
Postgraduate education & $66 \%$ \\
P/G courses & $80 \%$ \\
L ess than 1 year ago & \\
Frequency of antibiotic prescription & $9 \%$ \\
Daily & $64 \%$ \\
Weekly & $27 \%$ \\
M onthly + &
\end{tabular}

demonstrable lack of knowledge in some key areas including the incidence of adverse reactions, the development of multiresistant strains and difficulties in the appropriate use of prophylactic antibiotics. These findings parallel foreign studies of dental prescribing, although there is a higher level of knowledge in this study. ${ }^{16-18}$

The study population, although demographically representative of the general dental population of $\mathrm{SA}$, is biased. Of the overall sample, 32 (27 per cent) did not respond to three mailings and a further 17 (15 per cent) declined to participate for one reason or another. Those who did reply had a higher level of recent participation in postgraduate education than the whole dental population $(p<0.5)$. M any considered it a test and variously advised the researchers they had consulted references. T he views of the senior authors had been published in the A ustralian Dental J ournal two months prior to the study, ${ }^{19}$ so the results of this study may represent an overly favourable view of the situation.

The yardstick of the senior authors' opinions, although based on published guidelines and considerable experience and training, is not absolute. Clearly, other authorities could be expected to disagree on some aspects. Although antibiotic usage does have a scientific basis, there is a substantial basis for anecdotal opinion to influence practice.

Antibiotics only act against sensitive bacteria and they do so generally in the body and not at a single site. Thus, in therapeutic use, the essentials of removing the cause, draining pus, if present, and maximizing host resistance by controlling fever and dehydration are paramount. ${ }^{20}$ Reliance on antibiotics alone, and particularly broad spectrum rather than specific antibiotics, may result in failure to control infections and encourage the development of resistant bacterial strains.

The evidence for antibiotics acting to prevent infection from surgical wounds in the mouth is poor 
to non-existent. The incidence of wound infection following extractions is low, less than 3 per cent, so one is attempting to prevent a low and minor risk. ${ }^{21,22}$ The clinical indications for prophylactic antibiotics in endodontics are similarly low. Although the use of antibiotics, in particular tetracylines, has been in vogue for periodontal disease, the clinical evidence of benefit is low to non-existent. ${ }^{23}$

The issue of antibiotic prophylaxis and bacterial endocarditis is more defined. U ntreated bacterial endocarditis is a lethal condition and survivors may need valve replacement. G enerally, the medical and dental risk factors are well defined. One more recently identified risk, which was underestimated in this study, is endodontic treatment. Although bacterial showering from endodontic preparation is low and transient, the placement of the rubber dam, particularly with the rubber dam clamps, results in a substantial bacteraemia. T he authors are aware of at least two Australian cases of bacterial endocarditis where the rubber dam clamps placed during endodontic therapy were implicated. These cases resulted in indefensible litigation and hence were settled out of court. Antibiotic prophylaxis for endodontics with rubber dam is mandatory for atrisk patients. The use of antibiotic prophylaxis for patients with orthopaedic implants has been controversial. Recent studies show the risk to be exceedingly low and clearly far outweighed by the risk of adverse sequelae to the antibiotic. ${ }^{24}$

This study showed amoxycillin to be the overwhelming choice of antibiotic by most respondents. There was a tendency toward lower dosage over a longer period of time. If antibiotics are to be used, they are best prescribed in higher doses over a shorter period of time. The naturally occurring penicillins are effective against Gram-positive organisms only. The newer penicillins are acid stable when taken orally, however, greater blood levels are achieved when taken in a fasting state. Amoxycillin is a semisynthetic antibiotic derived from the penicillin nucleus and is stable in the presence of gastric acid even with food. Amoxycillin has the same G rampositive spectrum as benzylpenicillin but also has a Gram-negative spectrum which is similar to ampicillin. There is increasing evidence that quite a number of the Gram-negative organisms are developing resistance. $\mathrm{N}$ either of these antibiotics are effective against penicillinase-producing organisms. A part from the difference in the dosing regime, there are few microbiological reasons to use amoxycillin in preference for the spectrum of oral infections discussed in this paper. Amoxycillin's increased spectrum offers very little advantage and, theoretically, could be responsible for the development of resistant strains in non-oral pathogens.
In response to the questions on the alternatives for the patient who is allergic to penicillin, the overwhelming choice was erythromycin. Although this is the standard textbook answer, erythromycin is a weakly active, bacteriostatic antibiotic to most oral micro-organisms. Erythromycin is a macrolide type of antibiotic. It is susceptible to acid degradation when taken orally and is enteric coated in a glutenfree coating. The action of erythromycin is particularly against Gram-positive organisms. It is an inhibitor of protein synthesis and is only bacteriostatic in clinically tolerable doses. Resistance is a problem with erythromycin and can even develop during a course. This antibiotic has a high incidence of adverse effects such as nausea, vomiting, abdominal pain, diarrhoea and anorexia.

Fungi are difficult to treat as they survive in spore forms within the mucosal epithelial cells and are thus relatively inaccessible. Fungal infections are also commonly overdiagnosed. Hence, if fungal infection is suspected, then its presence must first be determined by cytology or culture. If present, then antifungals should be used for at least two weeks.

Antibiotic prescription is clearly a complex multifactorial issue. ${ }^{1-3}$ Obviously, health professionals with the right of prescription have a key but not sole role. Prescribers must have a thorough understanding of the clinical indicators for antibiotic prescription, both therapeutic and prophylactic. They also need an understanding of the risks of adverse reactions and the development of resistant and multiresistant strains. ${ }^{2,20} \mathrm{~T}$ his has to be in a population and global sense as well as for the individual patient in front of them.

Besides health professionals, the other key players are the pharmaceutical industry, the government and, last but not least, patients, both individual and the community. The pharmaceutical industry is often blamed for encouraging prescription of their products but this, after all, is their commercial responsibility. T he pharmaceutical industry is bound by government regulation and has a strong code of professional ethics. Thus, whether to prescribe or not remains the clinician's responsibility. H owever, pharmaceutical companies can and do influence the type of antibiotic used. Amoxycillin, as the apparently superior product over penicillin, is a classic example of this.

The Australian government has strong regulatory procedures in place and there is strict evaluation of all new drugs, strict control of type and quantity of drugs by means of the pharmaceutical benefits scheme (PBS) and regular bulletins to medical practitioners. Communication specifically with dental prescribers has been limited. Professional education, beginning at undergraduate medical and dental schools, is comprehensive, with continuing 
education via numerous publications. Again, communication specifically with dental practitioners has been brief and superficial. Despite this strong regulation and education, Australia has the second highest prescribing rate in the world. ${ }^{13} \mathrm{H}$ owever, the level of prescription has reached a plateau in the last five years, whereas in Europe and the US prescription levels continue to increase. This prescription plateau can be attributed to an ongoing educational campaign by Australian health authorities. These educational campaigns must be carefully and strategically conducted. ${ }^{25}$ Projects involving groups of medical practitioners and the community have shown that general medical practitioners will change their prescribing habits if they find their prescribing deviates from evidencebased national guidelines. As part of these projects, they have the opportunity to reflect on and discuss these differences in a group. ${ }^{26}$ Conversely, warnings of adverse reactions do not necessarily work. D espite warnings on adverse reactions to amoxycillin/ clavulanic acid, there was an increased prescription rate of 10 per cent and a 15 per cent increase in adverse hepatic reactions in the year following the warning. T his trend has now reversed. ${ }^{27}$

The community has a role in prescribing practice and, not surprisingly, after decades of unnecessary prescribing of antibiotics, they believe antibiotics are needed for most infections and demand that they be prescribed. Recent US and UK studies show this is not $50.28,29$ In the US and UK studies, individuals responded to unhurried discussion of the situation with a balanced view of the potential risks and benefits. For example, for children with acute otitis media, the probability of benefit is low and equal to the adverse risk. ${ }^{30} \mathrm{M}$ ost parents with a child with an acutely painful ear will want something done but will accept analgesics alone when advised spontaneous resolution will occur in 24 hours in 60 per cent of cases. With antibiotics, the improvement rate is similar but with the added risk of vomiting, diarrhoea or a rash. In rare cases, severe and occasionally fatal Stevens J ohnson syndrome can occur after antibiotic administration.

The dental profession as a whole needs to commit to a deeper understanding of the global effect of unnecessary antibiotic prescription. Antibiotics, if used wisely and discriminately, are precise life-saving drugs; however, if used indiscriminately, there are significant short-term and particularly long-term adverse sequelae. T he profession needs to play a role in ongoing patient and community education.

\section{Acknowledgement}

The authors wish to thank the South Australian D ental Board for permission to use the mailing list; Dr Ross Smith, Senior Consultant M icrobiologist,
Royal Adelaide Hospital, for advice on the manuscript; Mrs L Eves for assistance in administering the survey and typing the manuscript; and acknowledge all those who participated.

\section{References}

1. Turnidge J. Antibiotic use or misuse. (Editorial.) M ed J Aust 1997;167:116-117.

2. Turnidge J, Nimmo G, Francis G. Evolution of resistance in Staphylococcus aureus in Australian teaching hospitals. Australian Group on Antimicrobial Resistance. Med J Aust 1996;164: 68-71.

3. Anonymous. Penicillin allergy. D rugT her Bull 1996;34:87-88.

4. Collignon PJ, Bell JM. D rug resistant Streptococcus pneumoniae: the beginning of the end for many antibiotics? Australian G roup on Antimicrobial Resistance. M ed J Aust 1996;164:64-67.

5. Christiansen $K$. Pneumonia in the nineties. Aust Prescriber 1999;22:37-39.

6. Victorian Drug U sage Advisory Committee. Antibiotic guidelines. 10th edn. North M elbourne: Therapeutic Guidelines Limited, 1998.

7. Tolhurst JC, Buckle G, Williams SW. Chemotherapy with antibiotics and allied drugs. Canberra: $\mathrm{N}$ ational $\mathrm{H}$ ealth and M edical Research Council, Australian Government Publishing Service, 1972

8. Littler W, M CGowan DA, Conlon C, Shanson DC, Eykyn S, Swanton $\mathrm{H}$. A moxycillin prophylaxis for endocarditis prevention. British Society for Antimicrobial Chemotherapy Endocarditis Working Party. Br D ent J 1998;184:208.

9. ChengT O. Prevention of bacterial endocarditis: American H eart Association recommendations. JAM A 1997;278:1233.

10. Anonymous. Antibiotic prophylaxis of endocarditis. Aust Prescriber 1992;15:3.

11. Woods RG. A guide to the use of drugs in dentistry. 12th Edn. Sydney: Australian D ental Association, 1996.

12. Therapeutic Subcommittee. Bacterial endodartitis - prophylactic guidelines. Adelaide: Royal Adelaide H ospital, 1999.

13. $M$ cM anus $P, H$ ammond $M L$, Whicker SD, Primrose JG, $M$ ant A, Fairall SR. Antibiotic use in the Australian community, 199095. M ed J Aust 1997;167:124-127.

14. Steffensen FH, Schonheyder HC, Sorensen HT. High prescribers of antibiotics among general practitioners - Relation to prescribing habits of other drugs and use of microbiological diagnostics. Scand J Infect D is 1997;29:409-413.

15. Cars H, Hakansson A. To prescribe - or not to prescribe antibiotics. District physicians' habits vary greatly, and are difficult to change. Scand J Prim H ealth Care. 1995;13:3-7.

16. Preus HR, Albandar JM, Gjermo P. Antibiotic prescribing practices amongst Norwegian dentists. Scand J Dent Res 1992;100:232-235.

17. Ciancio S, Reynard A, Zielezny, M ather $M$. A survey of drug prescribing practices of dentists. N Y State Dent J 1989;55: 29-31.

18. Sadowsky D, Kunzel C. A study of the implementation of endocarditis prevention in patients at risk. NY State Dent J 1986;52:34-37.

19. Sambrook P, G oss AN . Antibiotic use, misuse and abuse. (L etter to the editor.) Aust D ent J 1998;43:201-202.

20. Bridgeman A, Wiesenfeld D, Hellyar A, Sheldon W. M ajor maxillofacial interactions. An evaluation of 107 cases. Aust D ent J 1995;40:281-288.

21. Piecuch JF, Arzadon J, Lieblich SE. Prophylactic antibiotics for third molar surgery: A supportive opinion. J Oral Maxillofac Surg 1995;25:53-60.

22. Zeitler DL. Propylactic antibiotics for third molar surgery. A dissenting opinion. J Oral M axillofac Surg 1995;25:61-64.

23. Lindhe J. Necrotising periodontal disease. In: Lindhe J, 
KarringT, Lang NP. Clinical periodontology and implant dentistry. 3rd Edn. Copenhagen: M unksgaard, Copenhagen, 1997.

24. Sandhu SS, Lowry JC, M orton ME, Reuben SF. Antibiotic prophylaxis, dental treatment and arthroplasty: time to explode a myth. (E ditorial.) J Bone Joint Surg 1997;79B:521-522.

25. Harvey $K$, Rogers $S$, Roughbad L. Initiative to improve antibiotic use. Aust Prescriber 1999; 22:26-28.

26. De Santis G, H arvey KJ, H oward D, M ashford M L, M oulds RF. Improving the quality of antibiotic prescriptions in general practice. The role of educational intervention. Med J Aust 1994;160:502-505.

27. Adverse Drug Reactions Advisory Committee. Antibiotics of continuing concern. Aust Adverse Drug Reactions Bull 1996;15:6-7.
28. H amm RM, Hicks RJ, Bemben DA. Antibiotics and respiratory infections: Are patients more satisfied when expectations are met? J Fam Pract 1996;43:56-62.

29. Butler CC, Rollnick S, Pill R, Maggs-Rapport F, Stott N. Understanding the culture of prescribing: Qualitative study of general practitioner's and patients' perceptions of antibiotics for sore throats. BM J 1998;317:637-642.

30. D el M ar C, Glasziou P, H ayem M. Are antibiotics indicated as initial treatment for children with acute otitis media? A metaanalysis. BM J 1997;314:1526-1529.

A ddress for correspondence/reprints:

Professor Alastair G oss,

Oral and M axillofacial Surgery U nit, 
The U niversity of Adelaide,

Adelaide, South Australia 5005. 